\title{
Cryogenian U-Pb (SHRIMP I) zircon ages of anorthosites from the upper sequences of Niquelândia and Barro Alto Complexes, Central Brazil
}

\author{
Ciro Teixeira Correia ${ }^{1}$, Vicente Antonio Vitorio Girardi', \\ Miguel Angelo Stipp Basei ${ }^{1}$ \& Allen Nutman ${ }^{2}$
}

\begin{abstract}
The Niquelândia Complex comprises two main superposed sequences dipping westward: the lower (LS), at the eastern, and the upper (US), at the western part of the body. The Complex is either interpreted as a single body, or as two distinct unrelated layered massifs. New SHRIMP U-Pb determinations on igneous zircon grains of anorthosites from Niquelândia US and from the upper portion of the Barro Alto Complex indicate crystallization ages of $833 \pm 21 \mathrm{Ma}$ and $733 \pm 25 \mathrm{Ma}$, respectively, thus supporting Cryogenian Neoproteroic ages for the igneous crystallization of the US unit of Niquelândia and for the Barro Alto anorthosites.
\end{abstract}

Keywords: Niquelândia, Barro Alto, anorthosites, U-Pb geochronology, Central Brazil.

Resumo Idades U-Pb (SHRIMP I) Criogenianas dos anortositos das seqüencias superiores dos Complexos de Niquelândia e Barro Alto, Brasil central. O Complexo de Niquelândia é formado por duas seqüências superpostas mergulhando para W: a inferior (LS) a leste, e a superior (US) na parte oeste do corpo. O complexo é interpretado como sendo uma intrusão única, ou como composto por duas intrusões distintas e não relacionadas. Novas determinações isotópicas efetuadas pelo método SHRIMP U-Pb em grãos de zircão ígneos de anortositos da unidade US de Niquelândia, e da porção superior do Complexo de Barro Alto indicaram idades de cristalização de $833 \pm 21$ Ma e $733 \pm 25$ Ma, respectivamente. Tais dados implicam na atribuição de idades Neoproterozóicas do Criogênico para a cristalização ígnea da unidade US de Niquelândia e para os anortositos de Barro Alto.

Palavras-chave: Niquelândia, Barro Alto, anortositos, geocronologia U-Pb, Brasil Central.

INTRODUCTION The Niquelândia (NQC) and Barro Alto (BAC) Complexes, in central Brazil, are among the largest anorogenic stratiform layered intrusions in the world. They belong to a $350 \mathrm{~km}$ long discontinuous, north-trending chain of mafic-ultramafic massifs, which also includes the northern Cana Brava (CBC) Complex and are located at the western side of the São Francisco craton, bordered by the Brasília Belt, in the Tocantins Province (Fig.1).

These bodies are of great geologic and economic significance to Brazil. The Niquelândia Complex is the principal Ni mining area, whereas the Barro Alto complex has huge reserves of laterite-hosted-Ni. The Cana Brava Complex hosts the largest asbestos mine in Brazil. All three bodies have been investigated for their potential to host platinum group element mineralization.

The main aim of this paper is to discuss new SHRIMP isotopic U-Pb zircon analyses from anorthosites of the upper units of the Niquelândia and Barro Alto complexes, in order to contribute to a better knowledge of the ages of the complexes, which are particularly significant for the tectonic evolution of the Tocantins Province and the western border of the São Francisco craton.
GEOLOGICAL OVERVIEW The NQC and the two other associated complexes are recognized as stratiform intrusions (Rivalenti et al. 1982, Girardi et al.1986, Feininger et al. 1991, Ferreira Filho et al. 1992, 1994, Oliveira \& Jost 1993, Correia 1994).

NQC is constituted of two main superposed sequences dipping westward: the lower (LS) at the eastern, and the upper (US) at the western part of the complex. LS consists of a basal gabbro zone (BGZ), made of gabbros and some interlayered pyroxenites and peridotites, a basal peridotite zone (BPZ), a layered ultramafic zone (LUZ), formed of pyroxenites with minor interlayered peridotites and gabbros, and the lower gabbro zone (LGZ). Two chromitite horizons ( $\mathrm{cm}$ to $\mathrm{dm}$ thick) occur in the LUZ zone (see Fig. 1, in Girardi et al. 1986, for details). LGZ is composed of melanocratic to leucocratic gabbros (plagioclase, augite, hypersthene, with minor and variable amounts of ilmenite, magnetite, sulphide and apatite), and some thin layers of websterite and peridotite close to the base of the zone. Cumulate igneous textures are locally well preserved. Mylonitic textures are common, associated with discrete shear zones. Amphibole appears before the middle portion of LGZ and increases in proportion upwards. The top of this layer, formerly called "hydrous zone" by Girardi et

1 - Departamento de Mineralogia e Geotectônica, Instituto de Geociências da Universidade de São Paulo, São Paulo (SP), Brasil. E-mails: ccorrei@usp.br, girardi@usp.br (corresponding author), baseimas@usp.br

2 - Research School of Earth Science, Australian National University, Camberra. E-mail: allen.nutman@anu.edu.au 


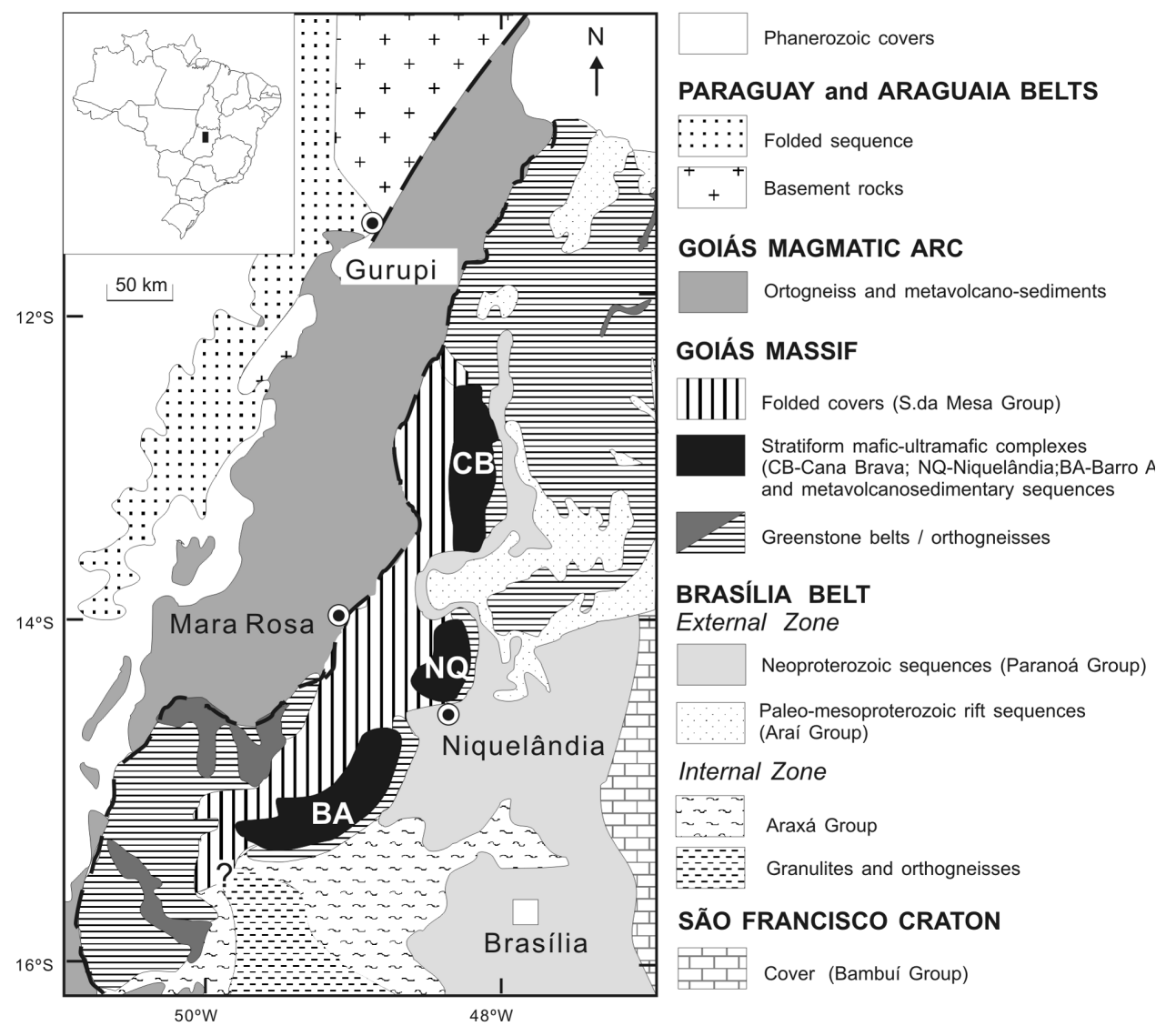

Figure 1 - Geological map of central-eastern part of the Tocantins Province (modified after Pimentel et al. 2004a).

al. (1986), due to the enrichment in biotite, hornblende, apatite, zircon, incompatible elements and LREE, is here designated "LGZ top zone", as proposed by Correia et al. (1996). At this level, biotite appears together with quartz, hornblende and orthopyroxene as major mineral phases, whilst apatite and zircon are significant components in several samples. The peculiar mineralogy of the gabbros of this zone is mainly due to the interaction with abundant country-rocks xenoliths, including quartzites, schists, calc-silicate rocks and gneisses.

US comprises two zones: the upper gabbroic zone (UGAZ) and the upper amphibolite zone (UA). UGAZ is composed of gabbro, anorthosite and some clinopyroxenite layers near its top. Cumulate textures (plagioclase and olivine cumulus, orthopyroxene intercumulus) and ophytic textures are quite common, as are corona textures derived from reaction between plagioclase and primary mafic phases (Candia et al. 1989). In the anorthosites, hornblende is the main mafic phase. UA lithotypes are layered amphibolite (hornblende, plagioclase, clinopyroxene, opaque minerals, \pm garnet). Some anorthosites occur at its base.

US is bordered by the Mesoproterozoic Indaianópolis metavolcano-sedimentary sequence, whereas LS is in tectonic contact with Paleoproterozoic granitegneiss terrains.

Although the preservation of primary igneous structures and mineral assemblages are common, the effects of a high temperature re-equilibration formerly attributed to a slow sub-solidus event (Girardi et al. 1986), and later ascribed to granulite-amphibolite facies metamorphism (Ferreira Filho et al. 1998), are important features.

The age and the stratigraphy of the complex are controversial. According to Girardi et al. (1986), the Niquelândia body represents a single igneous complex. Following this model, Correia et al. (1996), using SHRIMP U-Pb data in the LGZ top zone and the Re-Os systematic in LUZ, obtained an Re-Os age of $2.0 \mathrm{Ga}$ for the LS sequence, interpreted as the crystallization age of the entire Complex. U-Pb ages of $780 \mathrm{Ma}, 1000-$ $1400 \mathrm{Ma}$, and 1600-1880 Ma from the concordia were interpreted as probable periods of tensional relaxing due to extensional rifting in the area. Ferreira Filho et al. (1994) analyzed zircon grains from two rocks (CF 03, a diorite from LS, and CF-04, a quartz-rich mylonitic rock within gabbros of US) by conventional U-Pb method. The result was a poorly constrained discordia, where the upper intercept $(1.56 \mathrm{Ga})$ was interpreted as the crystallization age of the complex. The authors attributed an age of $794 \mathrm{Ma}$ to the metamorphism. Ferreira Filho \& Pimentel (2000) proposed that LS and US constitute two distinct layered complexes, yielding ages of $2.0 \mathrm{Ga}$ (LS) and $1.35 \mathrm{Ga}$ (US). However, the last age originated from poorly defined $\mathrm{Sm}-\mathrm{Nd}$ isochrons as mentioned by Pimentel et al. (2004b). The interval 770-795 Ma was interpreted as the period of high-grade metamorphism of 
both units. Pimentel et al. (2004b) using SHRIMP U-Pb zircon ages from the same samples (CF-03 and CF-04) formerly studied by Ferreira Filho et al. (1994), and Sm$\mathrm{Nd}$ data from Ni-376 (a gabbronorite of LS) concluded that LS and US yield respective igneous crystallization ages of 0.79 and $1.25 \mathrm{Ga}$.

The Barro Alto Complex (BAC) is an elongated, arch-shaped body. The northeastern part, according to Girardi et al. (1981), is composed of: 1) a Basal Zone consisting of metagabbros and amphibolites, 2) an Ultramafic Zone made of serpentinized metaperidotites, 3) an Anorthositic Zone composed of metagabbros and pyrigarnites and 4) an Upper Zone containing ophitic and blastophitic gabbros. Similarly to NQC, these units dip westward and are bordered to the east and to the west, respectively by Paleoproterozoic granite-gneiss terrains and the metavolcanic-sedimentary sequence of Juscelândia (Moraes et al. 2003).

The first geochronological data of BAC and its country rocks consist of $\mathrm{K}-\mathrm{Ar}$ and $\mathrm{Rb}-\mathrm{Sr}$ analyses (Hasui \& Almeida 1970, Souza 1983), which were discussed and summarized by Cordani \& Hasui (1975). The spread of obtained ages is very large (4000 to 500 $\mathrm{Ma}$ ) and their significance remains controversial due to analytical and sampling uncertainties.

According to Moraes \& Fuck (2000), BAC underwent granulite facies metamorphism. The mafic-ultramafic assemblage is composed mainly of gabbronorite, with minor amounts of dunite, peridotite, gabbro, anorthosite and banded clinopyroxenegarnet-amphibolite. Acid granulites and high-grade metasedimentary rocks included as lenses into the mafic-ultramafic suite were considered as part of the complex (Fuck et al. 1989). Two Rb-Sr isochron ages, the first originated from felsic granulites collected

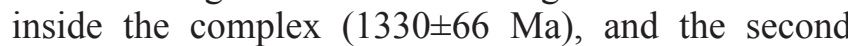
$(1266 \pm 17 \mathrm{Ma})$ related to gneissic country rocks from the Juscelândia metavolcano-sedimentary sequence at its western border were interpreted as related to metamorphism of those units, probably due to the continental collision between Goiás massif and the Neoproterozoic metamorphic units on its eastern border (Uruaçuano cycle, ca. 1.100-1.200 Ma, Hasui \& Almeida 1976). Suita et al. (1994) obtained the first U-Pb conventional zircon data for BAC. They analyzed zircons from a quartz-diorite sample and interpreted the $\mathrm{U}-\mathrm{Pb}$ upper concordia intercept of 1.72-1.73 $\mathrm{Ga}$ as the minimum igneous age for the Barro Alto complex. They also reported $\mathrm{U}-\mathrm{Pb}$ ages of $1.29-1.35 \mathrm{Ga}$ (upper intercept) and 0.77-0.82 Ga (lower intercept) from a pegmatitic gabbro of the complex. The upper intercept age was interpreted as a period of mafic magmatism related to the Uruaçuano cycle, or perhaps post-Barro Alto magmatism. The lower intercept age was attributed to the last metamorphic event during Brasiliano times. Correia et al. (1999) analysed zircon grains by U-Pb (SHRIMP II) methodology from an acid granulite containing quartz, cordierite, sillimanite, plagioclase and mesopertite, collected at the western border of the complex, close to the bimodal Juscelândia metavolcano-sedimentary se- quence; and a high grade metagranite located in centralnorthern part of the massif. These samples displayed respectively two groups of ${ }^{207} \mathrm{~Pb} /{ }^{206} \mathrm{~Pb}$ concordant ages of $1286 \pm 13 \mathrm{Ma}$ and $1302 \pm 32 \mathrm{Ma}$, interpreted as a Mesoproterozoic metamorphic overprint on older protoliths.

NEW U-Pb SHRIMP RESULTS The analyses were performed on zircon grains from two anorthosites: one from Niquelândia (NQ-1552: 95\% labradorite and minor amounts of green hornblende, epidote, scapolite and zircon; subhedral granoblastic texture; epidote locally euhedral in apparent equilibrium with plagioclase and hornblende; grain size between $0.5-3 \mathrm{~mm}$ ) and the other from Barro Alto (BA-1541: 92\% labradorite and minor amounts of hornblende, epidote and zircon; texture predominantly subhedral granoblastic, partially sheared; relicts of the original subophitic texture still preserved; grain size between 0.9-4 mm). NQ-1552 and BA-1541 are located at S $14^{\circ} 22^{\prime} 01^{\prime \prime}-\mathrm{W} 48^{\circ} 31^{\prime} 58^{\prime \prime}$ and S $15^{\circ} 05^{\prime} 17^{\prime \prime}-\mathrm{W} 49^{\circ} 02^{\prime} 25^{\prime \prime}$ respectively.

The radiometric analyses (Tables 1 and 2) were carried out at the Australian National University at Canberra, using SHRIMP I, according to the procedures presented by Compston et al. (1984), Williams (1998) and Stern (1998). The CZ3 standard was used for the isotopic corrections and calculation of element concentrations. Lead concentration corrections were based on the isotopic common $\mathrm{Pb}$ composition at the approximate time of rock formation (Cumming \& Richards 1975). The ages were calculated using the decay constants and the ${ }^{238} \mathrm{U} / 235 \mathrm{U}$ ratio value recommended by Steiger \& Jäger (1977). The isotope data were processed using the Isoplot Ex program (Ludwig 2001).

The cathodoluminescence images (Fig. 2) for both samples display a pale-gray homogeneous zircon pattern. Only few grains show clearly thin overgrowths and oscillatory growth zonation.

The results are plotted in Tera-Wasserburg diagrams, which show that the zircon populations in both samples have different ages. BAC (BA-1541) and NQC (NQ 1552) anorthosites yielded $733 \pm 25 \mathrm{Ma}$ and $833 \pm$ 21 Ma, respectively (Fig. 3).

DISCUSSION Pimentel et al. (2004b) published SRHIMP data on zircons from samples CF-04 (a quartz rich mylonite from a shear zone cutting gabbros, at the base of US, close to the limit of the LS top zone) and CF-03 (a diorite from LS top zone); and Sm-Nd data from Ni-376 (a gabbronorite from LS top zone).

Zircon crystals from both CF-03 and CF-04 display inherited cores bordered by overgrowth rims. Based on analysis of these rims and regions with oscillatory zoning from sample CF-03, the authors proposed a concordia age of $797 \pm 10 \mathrm{Ma}$, as representative of the igneous crystallization of the LS unit of Niquelândia. The Sm-Nd results from Ni-376 were not conclusive.

Sample CF-04 displayed zircon cores varying from 0.76 to $1.25 \mathrm{Ga}$. Based on four ${ }^{207} \mathrm{~Pb} /{ }^{206} \mathrm{~Pb}$ discordant analyses the authors interpreted the upper intercept 
Table 1 - SHRIMP I zircon data from NQ-1552 sample

\begin{tabular}{|c|c|c|c|c|c|c|c|c|c|}
\hline Label & Grain Type & $\mathrm{U} / \mathrm{ppm}$ & $\mathrm{Th} / \mathrm{U}$ & $\mathrm{Pb} * / \mathrm{ppm}$ & $204 / \mathrm{ppb}$ & $207 \mathrm{~Pb} / 206 \mathrm{~Pb}$ & $238 \mathrm{U} / 206 \mathrm{~Pb}$ & Age $6 / 38(\mathrm{Ma})$ & $\%$ Disc \\
\hline \multicolumn{10}{|c|}{ NQ1552 - corrected for common Pb using measured 204Pb (C\&R model $800 \mathrm{Ma})$} \\
\hline NQ-1.1 & $\mathrm{e}, \mathrm{h}, \mathrm{p}, \mathrm{fr}$ & 52.1 & 0.65 & 7 & 0 & $0.06523 \pm 0.00209$ & $7.98497 \pm 0.24957$ & $761 \pm 22$ & -3 \\
\hline NQ-2.1 & $\mathrm{m}, \mathrm{pr}, \mathrm{p}, \mathrm{h}$ & 52.1 & 0.59 & 7 & 1 & $0.06814 \pm 0.00123$ & $7.74906 \pm 0.30720$ & $782 \pm 29$ & -10 \\
\hline NQ-3.1 & $\mathrm{c}, \mathrm{h}, \mathrm{p}, \mathrm{r}$ & 66.4 & 0.72 & 12 & 2 & $0.07242 \pm 0.00154$ & $6.11241 \pm 0.17098$ & $977 \pm 25^{* *}$ & -2 \\
\hline NQ-4.1 & $\mathrm{e}, \mathrm{h}, \mathrm{p}, \mathrm{eq}$ & 53.7 & 0.64 & 8 & 1 & $0.07023 \pm 0.00190$ & $7.23063 \pm 0.24482$ & $835 \pm 27$ & -11 \\
\hline NQ-5.1 & $\mathrm{e}, \mathrm{h}, \mathrm{b}, \mathrm{fr}, \mathrm{r}$ & 22.9 & 0.38 & 3 & 0 & $0.07598 \pm 0.00260$ & $6.99232 \pm 0.25536$ & $862 \pm 30$ & -21 \\
\hline NQ 6.1 & e,h,p,r & 1.3 & 0.07 & 0 & 0 & $0.12628 \pm 0.03118$ & $7.43020 \pm 1.25236$ & $814 \pm 130$ ** & $* * *$ \\
\hline NQ-7.1 & $\mathrm{c}, \mathrm{h}, \mathrm{p}, \mathrm{eq}$ & 48.4 & 0.65 & 8 & 0 & $0.07515 \pm 0.00173$ & $6.81116 \pm 0.24965$ & $883 \pm 30$ & -18 \\
\hline NQ-8.1 & $\mathrm{c}, \mathrm{h}, \mathrm{p}, \mathrm{fr}$ & 14.1 & 0.09 & 2 & 0 & $0.07456 \pm 0.00559$ & $7.58327 \pm 0.36786$ & $799 \pm 37$ & -24 \\
\hline NQ-9.1 & $\mathrm{c}, \mathrm{h}, \mathrm{p}, \mathrm{pr}$ & 35.7 & 0.43 & 5 & 0 & $0.06799 \pm 0.00227$ & $7.51284 \pm 0.26367$ & $806 \pm 27$ & -7 \\
\hline NQ-10.1 & $\mathrm{e}, \mathrm{ov}, \mathrm{os}, \mathrm{pr}$ & 29.2 & 0.46 & 4 & 1 & $0.06888 \pm 0.00283$ & $7.16440 \pm 0.22686$ & $842 \pm 25$ & -6 \\
\hline NQ-11.1 & $\mathrm{c}, \mathrm{h}, \mathrm{p}, \mathrm{eq}$ & 43.0 & 0.69 & 6 & 1 & $0.06769 \pm 0.00202$ & $7.52480 \pm 0.26993$ & $804 \pm 27$ & -6 \\
\hline
\end{tabular}

Legend: c-core; e-end; m-middle; h-homog., p-pale, b-bright, r-round, pr-prismatic, eq-equant, fr-fragment, ov-overgrowth, os-oscil. zoning;

$*=$ radiogenic lead $* *=$ data not included in the weigthted average $* * *$ high discordant data

Table 2 - SHRIMP I zircon data from BA-1541 sample

\begin{tabular}{l|c|c|c|c|c|c|c|c|c|c}
\hline Label & Grain Type & $\mathrm{U} / \mathrm{ppm}$ & $\mathrm{Th} / \mathrm{U}$ & $\mathrm{Pb} / \mathrm{ppm}$ & $204 / \mathrm{ppb}$ & $207 \mathrm{~Pb} / 206 \mathrm{~Pb}$ & $238 \mathrm{U} / 206 \mathrm{~Pb}$ & Age 6/38(Ma) & $\%$ Disc. \\
\hline \multicolumn{8}{c}{ BA1541 corrected for common Pb using measured 204Pb (C\&R = 750 Ma) } \\
\hline BA-1.1 & c, h, p, fr & 20.5 & 0.65 & 3 & 0 & $0.06462 \pm 0.00431$ & $8.30021 \pm 0.32343$ & $733 \pm 27$ & -4 \\
\hline BA-2.1 & e, h, p, fr & 9.2 & 0.71 & 1 & 1 & $0.05469 \pm 0.01158$ & $8.13756 \pm 0.38479$ & $747 \pm 33$ & $* * *$ \\
\hline BA-3.1 & c, h, b, fr & 11.4 & 0.55 & 1 & 1 & $0.05973 \pm 0.00653$ & $8.21627 \pm 0.35312$ & $740 \pm 30$ & 25 \\
\hline BA-4.1 & e, p, pr & 13.1 & 0.46 & 2 & 0 & $0.06745 \pm 0.00452$ & $7.58177 \pm 0.36379$ & $799 \pm 36 * *$ & -7 \\
\hline BA-5.1 & c, pr, b & 8.8 & 0.49 & 1 & 1 & $0.06095 \pm 0.00591$ & $8.37734 \pm 0.52434$ & $727 \pm 43$ & 14 \\
\hline BA-6.1 & e, b, fr & 33.9 & 0.70 & 4 & 0 & $0.06578 \pm 0.00226$ & $8.39453 \pm 0.31542$ & $726 \pm 26$ & -10 \\
\hline BA-7.1 & c, h, b, r & 6.6 & 0.26 & 1 & 1 & $0.05038 \pm 0.01421$ & $8.37159 \pm 0.42791$ & $727 \pm 35$ & $* * *$ \\
\hline
\end{tabular}

Legend: c-core; e-end; h-homogeneous, p-pale, b-bright, r-round, pr-prismatic, fr-fragment $*$ = radiogenic lead $* *=$ data not included in the weigthted average $* * *$ high discordant data

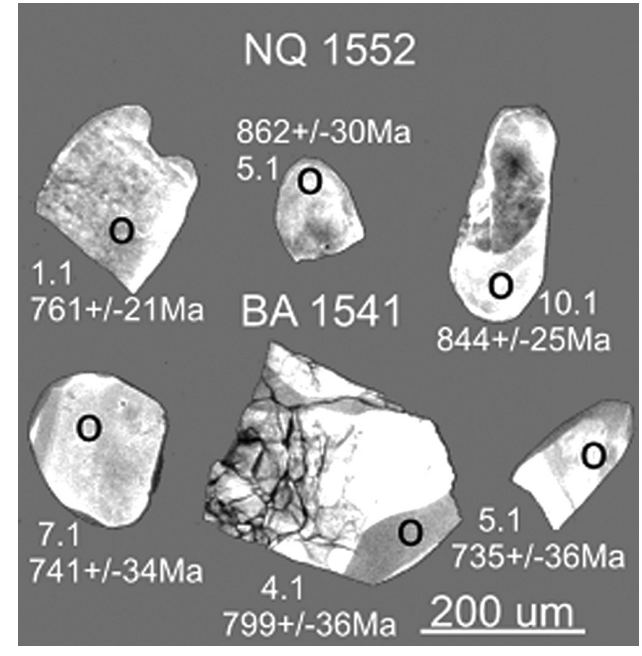

Figure 2 - Selected cathodoluminescence images of zircon grains from NQ-1552 and $B A-1541$ samples. Black circles indicate the analyzed areas.

age of $1248 \pm 23 \mathrm{Ma}$ as the igneous crystallization of the US unit of Niquelândia.
These interpretations and also the crystallization age proposed by Correia et al. (1996) and Correia (2001) are questionable due to the abundant countryrock xenoliths, which contaminate the LS top zone. The crustal contamination caused by the assimilation of these rocks by the intrusive magma possibly accounts for the particular geochemical characteristics of gabbros and diorites of this zone (see previous section). Both samples CF-03, and mainly CF-04, seem to be close to the limit between LS and US (see Fig. 3 in Pimentel et al. 2004b). Moreover CF-04 contains kyanite, which indicates contamination probably by metasediments. Therefore, it is not possible to distinguish between those zircon grains that came from the intrusion from the ones originated from the country-rocks. Thus, the age of $1248 \pm 23$ Ma may have no relationship with the igneous crystallization of the Niquelândia complex. In addition, the $1.35 \mathrm{Ga} \mathrm{Sm}-\mathrm{Nd}$ isochron from leucogabbros (Ferreira Filho \& Pimentel 2000) does not help to support the Mesoproterozoic age for US. It is poorly defined, as mentioned by Pimentel et al. (2004b), and also might be the result of mixing lines.

Petrographic studies and individual grain observation of the zircon populations from samples BA1541 and NQ-1552 display morphological igneous 

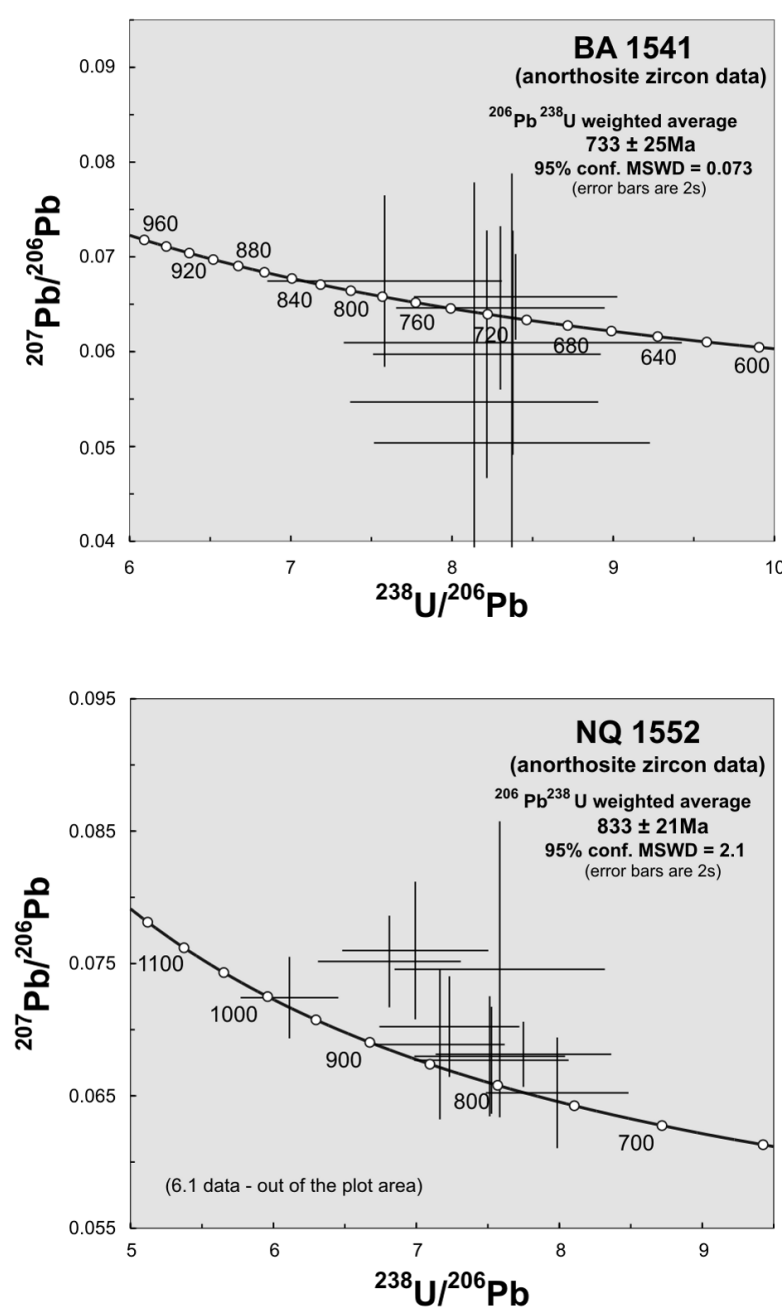

Figure 3 - Tera-Wasserburg plots for NQ 1552 and BA 1541 anorthosites zircon analysis

characteristics. All the individual crystals preserved from fragmentation are prismatic. The occasional faintrounded fragments differ from the typical spherical shaped metamorphic zircon. Moreover, cathodoluminescence images (see Fig. 2) confirm the igneous features: inherited old cores inside newly formed borders are absent in the zircon grains, as well as different zones displaying discontinuous oscillatory growth. Some grains show only very thin and localized overgrowths on the borders, which were avoided during SHRIMP I analysis. Besides, irregular shaped grains or crystals devoid of oscillatory growths are common in deep crystallized igneous mafic rocks.

Therefore the resulting ages should reflect the time of zircon crystallization of BA-1541 and NQ1552 samples. The absence of inherited cores does not support previous interpretations, which suggest a Mesoproterozoic age for the rocks from the upper units of NQC.

The morphological characteristics, the internal structure, homogeneity, and the predominant high $\mathrm{Th} / \mathrm{U}$ ratios (see Table 1) of the NQ-1552 anorthosite zircon crystals indicate that $833 \pm 21 \mathrm{Ma}$ can be interpreted as the crystallization age of the US unit of the Niquelândia complex. The $\varepsilon N d T$ of this sample is +3.5 , which indicates the influence of a previous depleted mantle source on the origin of the parental melt (Girardi et al. 2006a, 2006b).

$\mathrm{Th} / \mathrm{U}$ ratios, morphological and structural features of the BA-1541 anorthosite zircons are similar to those of the NQ-1552 sample (Fig. 2, Table 2). Therefore the obtained data $(733 \pm 25 \mathrm{Ma})$ can be associated to the crystallization age of the upper portion of BAC. However the stratigraphy of the massif is debatable and further studies are necessary to set up the geochronology of the whole Complex. On the other hand side, taking into account this reinterpretation on the age of the NQC upper sequence, and the geological and petrologic similarities of the bi-modal metavolcano-sedimentary sequences of Juscelândia and Indaianópolis, the 1286 $\pm 13 \mathrm{Ma}$ and $1302 \pm 32 \mathrm{Ma} \mathrm{U}-\mathrm{Pb}$ determinations by Correia et al. (1999), previously attributed to the Mesoproterozoic metamorphism of the complex, are now interpreted as related to age of the protoliths of the acid granulites included into the layered complex during the mafic-ultramafic intrusion.

Acknowledgements The authors acknowledge the Brazilian Agencies FAPESP (Proj. 2004/03032-6) and $\mathrm{CNPq}$ for financial support. We are also grateful to H.H.G.J. Ulbrich for reviewing the manuscript.

\section{References}

Candia M. A. F., Mazzucchelli M. \& Siena F. 1989. Sub-solidus reactions and corona structures in the Niquelândia layered complex (Central Goiás, Brazil). Mineral. Petrol., 40:17-37.

Compston W., Williams I.S. \& Meyer C. 1984. U-Pb geochronology of zircons from lunar breccia 73217 using a sensitive high mass-resolution ion microprobe. J. Geophys. Res., Supplement, 89:B525-B534.

Cordani U.G. \& Hasui Y. 1975. Comentários sobre dados geocronológicos disponíveis para a Folha Goiás. In: Brasil, DNPM. Carta Geológica do Brasil ao Milionésimo, Folha Goiás (SD 22) DNPM, DGM, p. 85-94.

Correia C.T. 1994. Petrologia do complexo máfico-ultramáfico de Cana Brava, Goiás. Tese de Doutorado, Instituto de
Geociências, Universidade de São Paulo, 151 p.

Correia C.T. 2001. O método Re-Os e o estudo da origem e da evolução tectônica dos grandes complexos máficosultramáficos, do Centro Oeste do Brasil. Tese de Livre Docência, IGc, Universidade São Paulo, 59 p.

Correia C.T., Girardi V.A.V., Lambert D.D., Kinny P.D. \& Reeves S.J. 1996. 2 Ga U-Pb (SHRIMP II) and Re-Os ages for the Niquelândia basic-ultrabasic layered intrusion, Central Goiás, Brazil. In: SBG, Cong. Bras. Geol., 39, Salvador, Anais, v.6, p. 187-189.

Correia C.T., Jost H., Tassinari C.C.G., Girardi V.A.V. \& Kinny P.D. 1999. Ectasian Mesoproterozoic U-Pb ages (SHRIMP II) for the metavolcano-sedimentary sequences of Juscelândia and Indaianópolis and for the high grade 
metamorphosed rocks of the Barro Alto stratiform igneous complex, Goiás State, Central Brazil. In: South American Symposium on Isotopic Geology, 2, Cordoba, Argentina, Actas, p. 31-33.

Cumming G.L. \& Richards J.R. 1975. Ore lead isotope ratios in a continuously changing Earth. Earth Plan. Sci. Lett., 28:155-171.

Feinenger T., Dantas J. J. \& Girardi V.A.V. 1991. Gravity interpretation and possible regional significance of the Niquelândia layered basic-ultrabasic complex, Goiás, Brazil. J. South Am. Earth Sci., 4(4):343-350.

Ferreira Filho C.F., Kamo S.L., Fuck R.A., Krogh T.E. \& Naldrett A.J. 1994. Zircon and rutile U-Pb geochronology in the Niquelândia layered mafic-ultramafic intrusion, Brazil: constraints for the timing of magmatism and highgrade metamorphism.Precambrian Res.,68(3-4):241-256.

Ferreira Filho C.F., Moraes R., Falcett J.J. \& Naldrett A.J. 1998. Amphibolite to granulite progressive metamorphism inf the Niquelândia Complex, Central Brazil: regional tectonic implications. J. South Am. Earth Sci., 11:35-50.

Ferreira Filho C.F., Nilson A.A. \& Naldrett A.J. 1992. The Niquelândia mafic-ultramafic complex, Goiás, Brazil: A contribution to the ophiolite $\mathrm{x}$ stratiform controversy based on new geological and structural data. Precambrian Res., 59:125-143.

Ferreira Filho C.F. \& Pimentel M.M. 2000. Sm-Nd isotope systematics and REE data for leucotroctolites and their amphibolitized equivalents of the Niquelândia Complex upper layered series, central Brazil: further constraints for the timing of magmatism and high-grade metamorphism. J. South Am. Earth Sci., 13:647-659.

Fuck R.A., Brito Neves B.B., Cordani U.G. \& Kawashita K. 1989. Geocronologia Rb-Sr no complexo Barro Alto, Goiás, evidência de metamorfismo de alto grau e colisão continental há 1300 Ma no Brasil Central. Geoch. Bras., 3(2):128-140.

Girardi V.A.V., Rivalenti G., Siena F. \& Sinigoi S. 1981. Precambian Barro Alto Complex of Goiás, Brazil: Bulk geochemistry and phase equilibria. N. Jb. Miner. Abh., 142(3):270-291.

Girardi V.A.V., Rivalenti G. \& Sinigoi S. 1986. The petrogenesis of the Niquelandia layered basic-ultrabasic complex, Central Goiás, Brazil. J.Petrol.,27(3):715-744.

Girardi V.A.V., Ferrario A., Correia C.T. \& Diella V. 2006a. A comparison of selected Precambrian Brazilian chromitites: Chromite, PGE-PGM, Re/Os as parental source indicators. J. South Am. Earth Sci., 20:303-313.

Girardi V.A.V., Rivalenti G., Correia C.T., Tassinari C.C.G., Munhá J.M. \& Mazzucchelli M. 2006b. Crustal contamination in the Niquelândia Complex, Central Goias, Brazil: Sr-Nd isotopes and trace-element geochemistry. In: South American Symposium on Isotopic Geology, 5, Punta del Este, Uruguay, Short Papers , p. 375-381.

Hasui Y. \& Almeida F.F.M. de 1970. Geocronologia do Centro-Oeste Braswileiro. Bol. Soc. Bras. Geol., 19(1):5-26.

Hasui Y. \& Almeida F. F. M. de 1976. A faixas de dobramentos Uruaçu no Brasil Central. In: Congr. Latino Americano de Geol., México, Resumenes, v.3, p. 62-63.

Ludwig K.R. 2001. User's manual for Isoplot/Ex. V.2.47. A geochronological toolkit for Microsoft Excel. BGC Special Publication. 1a, Berkeley, 55 p.

Moraes R. \& Fuck R.A. 2000. Ultra-high temperature metamorphism in Central Brazil: the Barro Alto complex. $J$. Metam. Geol., 18:345-358.

Moraes R., Fuck R.A, Pimentel M.M., Gioia S.M.C.L. \& Figueiredo A.M.G.F. 2003. Geochemistry and Sm-Nd isotopic characteristics of bimodal volcanic rocks of Juscelândia, Goiás, Brazil: Mesoproterozoic transition from continental rift to ocean basin. Precambrian Res., 125:317-336.

Oliveira A.M. \& Jost H. 1993. Estratigrafia, geoquímica e distribuição dos elementos do grupo da platina (EGP) do complexo de Barro Alto na região de Goianésia, Goiás. In: Encontro Brasileiro sobre Minerais do Grupo da Platina, 1, Resumos Exp., p. 18-19.

Pimentel M.M., Jost H. \& Fuck R.A. 2004a. O embasamento da Faixa Brasília e o arco magmático de Goiás. In: V. Mantesso Neto, A. Bartorelli, C.D.R. Carneiro \& B.B. Brito Neves (eds.) Geologia do Continente Sul-Americano: evolução da obra de Fernando Flávio Marques de Almeida, p. 355-358.

Pimentel M.M., Ferreira Filho C.F. \& Amstrong R.A. $2004 \mathrm{~b}$. SHRIMPU-Pb and Sm-Nd ages of the Niquelândia layered complex: Meso-(1.25 Ga) and Neoproterozoic (0.79 Ga) extensional events in central Brazil. Precambrian Res., 132:132-135.

Rivalenti G., Girardi V.A.V., Sinigoi S., Rossi A. \& Siena S. 1982. The Niquelândia mafic-ultramafic complex of Central Brazil: petrological considerations. Rev. Bras. Geoc., 12:380-391.

Souza A. 1983. Aspectos geológicos e geocronológicos do complexo de Barro Alto, Goiás. Tese de Doutorado, Faculdade de Filosofia, Ciências e Letras de Ribeirão Preto, Universidade de São Paulo, 112 p.

Steiger R.H. \& Jäger E. 1977. Subcommission on geochronology: Convention on the use of decay constants in geo- and cosmochronology. Earth Plan. Sci. Lett., 36:359-362.

Stern R.A. 1998. High resolution SIMS determination of radiogenic trace-isotope ratios in minerals. In: L.J. Cabri \& D.J. Vaughan (eds.) Modern Approches to Ore and Environmental mineralogy. Mineralogical Association of Canada, Short Course Series, v.27, p. 241-268.

Suita M.T.F., Kamo D.L., Krog T.E., Fyfe W.S. \& Hartman L.A. 1994. U-Pb ages from the high-grade Barro Alto mafic-ultramafic complex (Goiás, Central Brazil): middle Proterozoic magmatism and Upper Proterozoic continental collision. Abstracts of the Eighth Int. Conf. Geochr. Cosmoch. and Isotope Geol. (ICOG8), U. S. Geol. Surv. Circ., 1107:309.

Williams I.S. 1998. U-Th-Pb geochronology by ion microprobe. In: M.A. McKibben, W.C. Shanks III \& W.I. Ridley (eds.) Applications of microanalytical techniques to understanding mineralising processes, Society of Economic Geologists, Rev. Econ. Geol., 7:1-35.

Manuscrito CSF-01 Submetido em 12 de maio de 2006 Aceito em 23 de outubro de 2006 